\title{
EFEKTIFITAS MODEL LATIHAN KESEIMBANGAN BADGAN DAN MODEL LATIHAN KESEIMBANGAN KONVENSIONAL TERHADAP HASIL PEMANJATAN PADA OLAHRAGA PANJAT DINDING UNTUK PEMANJAT PEMULA
}

\author{
Bayu Hardiyono ${ }^{1}$, Nurkadri ${ }^{2}$, \\ ${ }^{1}$ FKIP Universitas Bina Darma \\ ${ }^{2}$ Fakultas Ilmu Keolahragaan, Universitas Negeri Medan \\ Bayuhardiyono@gmail.com,nurkadri171214@gmail.com
}

\begin{abstract}
Abstrak : Tujuan penelitian ini untuk mengetahui efektifitas model latihan keseimbangan badgan dan model latihan keseimbangan konvensional terhadap hasil pemanjatan pada olahraga panjat dinding untuk pemanjat pemula. . Metode penelitian ini menggunakan pendekatan kuantitatif digunakan untuk mencari efektifitas tersebut dengan rancangan penelitian eksperimen. Populasi dalam penelitian ini adalah anak usia 14-16 tahun anggota perkumpulan panjat dinding kota Palembang yang berjumlah 30 orang. Dalam pengambilan sempel ini menggunakan teknik total sampel, Dari 30 sampel pemanjat akan dibagi menjadi 2 kelompok, kelompok model latihan keseimbangan Badgan dan latihan konfensional, dengan teknik purposive sampling meliputi: (1) peserta latih sanggup mengikuti latihan selama 16 kali pertemuan, dan (2) rentang usia 14-16 tahun, Instrument tes menggunakan tes pemajatan. Uji analisis yang digunakan penelitian ini adalah uji beda rata-rata dengan menggunakan analisis uji-t (Paired $t$-test). Hasil daripenelitian ini menunjukkan rata-rata hasil post test kolompok model latihan keseimbangan Badgan mencapai 27 dan kelompok model latihan keseimbangan konfensional mencapai 25,439. selanjutnya setelah dimasukkan ke dalam rumus $t$, nilai t hitung $=2,750$, artinya $t$ hitung lebih besar dari pada t tabel yaitu 2,450>2,144 dengan $\mathrm{a}=5 \%$ dan $\mathrm{dk} 14$. Dengan demikian dapat di jelaskan bahwa terdapat perbedaan yang signifikan antara data post test dari kelompok model latihan keseimbangan Badgan dengan kelompok keseimbangan konfensional.
\end{abstract}

Kata Kunci : Efektifitas, Keseimbangan, Pemanjat Pemula

\section{PENDAHULUAN}

Mencetak atlet berprestasi tidak bisa secara instan, akan tetapi memerlukan waktu yang cukup panjang dengan tahapan tertentu yang harus berkesinambungan dan terpadu (Soegiyanto KS, 2004:1). Proses pembinaan yang berjangka panjang perlu dilaksanakan secara terencana, terprogram dan harus memiliki tujuan yang pasti tidak bisa dilaksanakan secara apa adanya (Yunyun Yudiana, 2009:2.4). Faktor pembinaan menyangkut masalah pembinaan itu sendiri seperti guru, pelatih, kemudian metode dan sistem latihan.

Keberhasilan seorang pembina, guru, pelatih, dalam meningkatkan prestasi anak didiknya antara lain tergantung pada pemakaian sarana dan prasarana serta penerapan teori peningkatan kondisi fisik anak didiknya. Menurut UU Nomor 3 Tahun 2005 pembinaan olahraga prestasi diselenggarakan oleh Pemerintah yang diwakili oleh Kemenpora dan dibantu pelaksanaannya oleh KONI. Pemerintah bertindak sebagai fasilitator dan penyandang dana pembinaan olahraga prestasi, sedangkan KONI sebagai pihak yang menjalankan pembinaan olahraga tersebut.

Salah satu pembinaan yang berada dilingkungan kota Palembang adalah panjat dinding, Panjat dinding merupakan salah satu olahraga tantangan dan mempunyai resiko yang sangat besar. Cabang olahraga ini dulunya berasal dari panjat tebing. Dalam perkembangannya, olahraga panjat tebing dimodifikasi menjadi panjat dinding yang membedakan panjat tebing dengan panjat dinding adalah medianya.

Panjat dinding medianya tebing buatan sedangkan panjat tebing medianya tebing alam. Olahraga panjat dinding sebagai salah satu cabang olahraga yang penuh tantangan dan resiko, olahragan ini juga telah menarik muda-mudi untuk berperstasi. Terlebih lagi olahraga tersebut telah diperlombakan pada tingkat nasional maupun initernasional. Adanya perlombaan-perlombaan juga telah mendorong mereka yang berkecimpung didalamnya untuk terus memacu prestasi. Upaya tersebut mengarah kepada kemungkinan untuk mengembangkan dalam 
meningkatkan kemampuan individu atlet panjat dinding mencapai keberhasilan pemanjatan.

Keberhasilan selalu dikaitkan dengan tujuan dari suatu kegiatan. Tujuan dari panjat dinding adalah menyelesaikan panjatan dengan teknik yang benar dan fisik yang baik serta mental yang tangguh. Oleh karena itu keberhasilan pemanjatan diidentikan dengan penyelesaian pemanjatan sampai ke poin akhir dengan menggunakan kemampuan atlet panjat dinding. Kemampuan yang dominan terlihat adalah teknik pemanjatan yang didukung dengan kondisi fisik yang baik.

Pelaksanaan pembinaan dan pelatihan panjat dinding perlu adanya suatu program yang dapat dijadikan sebagai acuan atau pedoman dalam melaksanakan agar berhasil sesuai dengan yang direncanakan. Dalam kegiatan pembinaan dan pelatihan panjat dinding di Perkumpulan panjat dinding kota Palembang mempunyai program atau bentuk-bentuk latihan yang telah diterapkan, antara lain, bentuk-bentuk program latihan.

Kategori kesulitan merupakan salah satu kelompok atau kelas yang dilombakan dalam olahraga panjat dinding dengan cara menempuh jalur yang telah ditentukan dengan tingkat kesulitan (grade) tertentu. Bagi pemanjat yang dapat mencapai ketinggian tertentu dan paling tinggi diantara pemanjat lainnya, itulah juaranya. Teknik pemanjatan dalam kategori ini menggunakan sistem leading, diamankan (dibelai) dari bawah dan pemanjat wajib mengaitkan tali pengamannya pada cincin kait pada runner setiap akan melewati runner di sepanjang jalur yang dilewati . Melihat beratnya kategori lead ini maka perlu kondisi fisik yang baik.

Salah satu kondisi fisik yang dominan pada olaharaga panjat dinding yang dibutuhkan dalam kategori difficult adalah keseimbangan, Atlet panjat dinding yang mempunyai kemampuan keseimbangan yang baik akan lebih mudah menyelesaikan suatu panjatan, keseimbangan berguna dalam upaya menjaga ketahan tubuh ketika memanjat.

Keseimbangan merupakan salah satu faktor yang sangat menentukan dan sangat penting bagi manusia, baik untuk seorang atlet/olahragawan maupun untuk aktifitas sehari-hari, baik dalam keadaan diam atau bergerak. Keseimbangan tidak hanya diperlukan untuk menyempurnakan teknik dan taktik saja, tetapi keseimbangan juga merupakan salah satu unsur kondisi fisik yang diperlukan dalam usaha mendukung peningkatan prestasi karena dalam penerapannya dipengaruhi oleh situasi dan kondisi lingkungan sekitarnya.

Keseimbangan adalah kemampuan mempertahankan sikap dan posisi tubuh secara tepat pada saat berdiri static balance atau pada saat melakukan gerakan dynamic balance (Widiastuti,2011:144). Keseimbangan juga bisa diartikan sebagai kemampuan relatif untuk mengontrol pusat massa tubuh (Center Of Mass) atau pusat gravitasi (Center Of Gravity) terhadap bidang tumpu (base of support). Keseimbangan melibatkan berbagai gerakan di setiap segmen tubuh dengan di dukung oleh sistem muskuloskleletal dan bidang tumpu. Kemampuan untuk menyeimbangkan massa tubuh dengan bidang tumpu akan membuat manusia mampu untuk beraktivitas secara efektif dan efisien.

Keseimbangan statik dan dinamik sangat diperlukan dalam setiap cabang olahraga, khususnya olahraga panjat dinding. Atlet panjang dinding yang mempunyai keseimbangan baik, akan mudah untuk memanjat hingga sampai titik atas (top poin). Keseimbangan merupakan interaksi yang kompleks dari integrasi/interaksi sistem sensorik (vestibular, visual, dan somatosensorik termasuk proprioceptor) dan muskuloskeletal (otot, sendi, dan jar lunak lain) yang dimodifikasi/diatur dalam otak (kontrol motorik, sensorik, basal ganglia, cerebellum, area asosiasi) sebagai respon terhadap perubahan kondisi internal dan eksternal. Dipengaruhi juga oleh faktor lain seperti, usia, motivasi, kognisi, lingkungan, kelelahan, pengaruh obat dan pengalaman terdahulu.

Kemampuan tubuh untuk mempertahankan keseimbangan dan kestabilan postur oleh aktivitas motorik tidak dapat dipisahkan dari faktor lingkungan dan sistem regulasi yang berperan dalam pembentukan keseimbangan. Tujuan seorang pemanjat mempertahankan keseimbangannya adalah menyanggah tubuh melawan gravitasi dan faktor eksternal lain, untuk mempertahankan pusat massa tubuh agar seimbang dengan bidang tumpu, serta menstabilisasi bagian tubuh ketika seorang pemanjat dinding bergerak untuk menambah ketinggian.

Menurut pendapat lain tentang keseimbangandiyatakan oleh Iskandar Z. Adisapoetra mengmukakan bahwa keseimbangan adalah kemampuan untuk mempertahankan sikap dan posisi tubuh secara tepat pada saat berdiri (static balance) atau pada saat melakukan gerakan (dynamic balance). Pada panjat dinding, gerakan panjat hanya bertumpu pada bidang yang sempit namun harus bisa mempertahankan gerakan agar tidak jatuh atau gagal. Keseimbangan dinamis dibutuhkan saat atlet melakukan pemanjatan. Namun keseimbangan statis juga dibutuhkan saat atlet bergantung dan akan mengambil poin untuk diraih. aktivitas tersebut mengharuskan pemanjat melakukan gerakan dengan cepat dan kuat mulai dari posisi sikap yang statis dan dinamis atau dalam aktivitas bergerak seperti memindahkan tubuh dari datu titik ke titik lainnya.

Pusat gravitasi didefinisikan dalam biomekanik sebagai titik imajiner. mewakili pusat berat suatu benda, di mana semua bagian tubuh menyeimbangkan satu sama lain. Mempertahankan posisi yang seimbang dalam pemanjatan untuk jangka waktu yang lama adalah yang terpenting selama pertandingan. Misalnya, pada saat seseorang pemanjat melakukan gerakan perpindahan tubuh ke kanan atau ke kiri untuk meraih poin yang ditentukan 
oleh pembuat jalur pemanjatan, atlet lebih berkonsentras, pada mempertahankan keseimbangan tubuhnya.

Berbicara tentang keseimbangan itu sendiri tidak lepas dari kestabilan, karena kestabilan adalah suatu kegiatan untuk menahan seluruh gaya yang mempengaruhi susunan tubuh manusia agar tetap seimbang. Gaya yang dimaksud adalah tenaga internal dan eksternal yang bekerja pada tubuh. Jadi memelihara keseimbangan yang terkendali tanpa menghiraukan berbagai tenaga internal dan eksternal yang bekerja pada tubuh atau anggota tubuh, merupakan suatu prasyarat dasar agar keterampilan menendang berhasil. Tenaga internal yang dimaksud adalah tenaga yang sumbernya di dalam tubuh (tenaga otot). Sedangkan tenaga eksternal adalah tenaga yang sumbernya berada di luar tubuh (hambatan udara, grafitasi, tenaga reaksi, tenaga lawan).

Berdasarkan uraian di atas, maka saat memanjat, konsep keseimbangan dalam menahan gaya internal dan eksternal yang bekerja pada tubuh dan dalam memindahkan berat badan sedemikian rupa sehingga memungkinkan gerakan tendangan menjadi lebih cepat dan kuat. Berdasarkan observasi pada perkumpulan di kota Palembang, latihan keseimbangan pada olahraga panjat dinding belum menggunakan program latihan yang jelas dan memiliki bermacam model latihan keseimbangan.

Hal ini dikarenakan masih banyaknya pelatih panjat dinding di kota palembang yang tidak memiliki latar belakang pendidikan olahraga khususnya panjat dinding. Selain itu, beberapa pelatih yang tahu tentang model-model latihan panjat dinding tidak terlalu memahami urutan dari tingkat kesulitan, dosis latihan dan beban latihan. Akibatnya, banyak atlet yang mengalami kebosanan dalam latihan sehingga pencapaian prestasi dalam panjat dinding menjadi tidak maksimal. Oleh karena itu peneliti melakukan pengembangan model latihan keseimbangan BADGAN untuk pemain pemula.

Berdasarkan latar belakang diatas maka penelitian ini akan mencari seberapa besar efektifitas model latihan keseimbangan BADGAN pada olahraga panjat dinding terhadap peningkatan hasil keseimbangan pada pemanjat pemula yang ada dikota palembang.

\section{METODE}

Jenis dalam penelitian ini adalah eksperimen, eksperimen adalah suatu cara untuk mengungkapkan suatu hubungan antara dua variabel atau lebih dan juga untuk mencari pengaruh suatu variabel terhadap variabel lainnya (Maksum, 2009). Sedangkan Menurut (Sudjana 2002:148) eksperimen faktorial adalah eksperimen yang hampir atau semua taraf sebuah faktor dikombinasikan atau disilangkan dengan semua taraf tiap faktor lainnya yang ada dalam eksperimen.

Populasi dalam penelitian ini adalah anak usia 14-16 tahun anggota perkumpulan panjat dinding kota Palembang yang berjumlah 30 orang. Dalam pengambilan sempel ini menggunakan teknik total sampel, Dari 30 sampel pemanjat akan dibagi menjadi 2 kelompok, kelompok model latihan keseimbangan Badgan dan latihan latihan konfensional, dengan teknik purposive sampling meliputi: (1) peserta latih sanggup mengikuti latihan selama 16 kali pertemuan, dan (2) rentang usia 14-16 tahun, Instrument tes menggunakan tes pemajatan. Teknik analisis data menggunakan IBM SPSS for Windows 21 dengan langkah menurut sugiono (2008).

\section{HASIL DAN PEMBAHASAN}

Hasil dari pre test dan post test yang dilakukan selama 16 kali pertemuan ini terdapat perbedaan yang dihasilkan dari masing-masing kelompok baik kelompok eksperimen model latihan keseimbangan Badgan dan model latihan konvensional. Hasil tes tersebut akan dicatat dan dihitung berdasarkan kelompok dan jenis latihan yang diberikan. Di sini akan dianalisis hasil dari ke empat kelompok tersebut berdasarkan data hasil penelitian menggunakan program IBM SPSS for Windows 21 selanjutnya deskripsi data hasil penelitian dapat dijabarkan lebih lanjut dalam bentuk tabel sebagai berikut:

Tabel 1. Hasil Perbedaan Pre Test Pemanjatan Pada Kelompok Model Latihan Keseimbangan Badgan dan Model Latihan Keseimbangan Konvensional Pada Pemanjat Pemula.

\begin{tabular}{cccccc} 
Kelompok & $\mathrm{N}$ & Rata-rata & T hitung & T tabel & Keterangan \\
\hline Eksperimen 1 & 15 & 21,5 & 1,968 & 2,144 & Tidak berbeda \\
Eksperimen 2 & 15 & 20,472 & & & signifikan
\end{tabular}


Tabel 2. Hasil Perbedaan Post Test Pemanjatan Pada Kelompok Model Latihan Keseimbangan Badgan dan Model Latihan Keseimbangan Konvensional Pada Pemanjat Pemula.

\begin{tabular}{cccccc} 
Kelompok & N & Rata-rata & T hitung & T table & Keterangan \\
\hline Eksperimen 1 & 15 & 27 & 2,750 & 2,144 & Berbeda \\
Eksperimen 2 & 15 & 25,439 & & & signifikan \\
\hline
\end{tabular}

Tabel 3. Uji Beda Hasil Pre-Test dan Post-Test Kelompok Model Latihan Keseimbangan Badgan.

\begin{tabular}{cccccc}
\hline Kelompok & N & Rata-rata & T hitung & T tabel & Keterangan \\
\hline Pre-test & 15 & 21,5 & 5,743 & 2,144 & Berbeda \\
Pos-test & 15 & 27 & & & signifikan \\
& & & & \\
\hline
\end{tabular}

Tabel 4. Uji Beda Hasil Pre Test dan Post Test Kelompok Model Latihan Konvensional

\begin{tabular}{cccccc}
\hline Kelompok & N & Rata-rata & T hitung & T tabel & Keterangan \\
\hline Pre-test & 15 & 20,472 & 4,567 & 2,144 & Berbeda \\
Pos-test & 15 & 25,439 & & & signifikan \\
\hline
\end{tabular}

Tabel 1 tersebut dapat terlihat bahwa nilai $\mathrm{t}$ hitung lebih kecil dari pada $\mathrm{t}$ tabel untuk $\alpha 5 \%$ dengan $\mathrm{dk}=14$, hal ini terbukti bahwa tidak ada perbedaan yang signifikan antara kelompok eksperimen model latihan keseimbangan Badgan dan kelompok eksperimen model latihan konvensional atau dianggap sama. Dengan data tersebut dapat diuraikan bahwa untuk peningkatan hasil pemanjatan pada antara kelompok eksperimen model latihan keseimbangan Badgan dan kelompok eksperimen model latihan konvensional perlunya pemberian perlakuan atau latihan keseimbangan minimal 16 kali pertemuan dengan progam tertentu yang dapat meningkatkan hasil pemanjatan.

Tabel 2 di atas dapat dilihat bahwa nilai $t$ hitung lebih besar dari pada $t$ tabel yaitu $t$ hitung 2,750 dan $t$ tabel 2,144. Hal ini berarti terdapat perbedaan yang sangat signifikan antara hasil data post test antara kelompok eksperimen model latihan keseimbangan Badgan dan kelompok eksperimen model latihan konfensional. Dengan demikian dapat diuraikan bahwa terdapat perbedaan pengaruh yang signifikan antara kelompok eksperimen model latihan keseimbangan Badgan dan kelompok eksperimen model latihan konvensional pada pemanjat pemula.
Uji hasil perbedaan rata-rata pre-test dan post-test pada masing-masing kelompok dimaksudkan agar apakah ada perbedaan yang signifikan dari masingmasing kelompok baik kelompok eksperimen model latihan keseimbangan Badgan dan kelompok eksperimen model latihan konvensional yang dapat mempengaruhi ketepatan pemanjatan tersebut. Oleh sebab itu perlu adanya uji beda dan hasil rata-rata baik pre test maupun post test.

Data tabel 3 tersebut dapat dilihat hal ini berarti bahwa ada perbedaan yang berarti antara data pre test dan data post test hal tersebut dapat dijelaskan bahwa terjadi peningkatan dari hasil pemanjatan pada Kelompok model latihan keseimbangan Badgan setelah dikenakan perlakuan selama 16 kali pertemuan sehingga perlakuan tidak percuma perlakuan dilakukan dan peningkatan tersebut diakibatkan oleh pemberian perlakuan yang telah dilakukan.

Data tabel 4 tersebut di atas dapat dilihat bahwa $\mathrm{t}$ hitung lebih besar dari pada t tabel yang berarti bahwa ada perbedaan dari data hasil pre-test dan post-test kelompok model latihan konvensional. Dengan demikian dapat diuraikan bahwa kelompok 
eksperimen model latihan keseimbangan Badgan dan kelompok eksperimen model latihan konvensional.

\section{KESIMPULAN}

Berdasarkan hasil penelitian dan hasil analisis data yang telah dilakukan, dapat diperoleh kesimpulan sebagai berikut: (1) Terdapat pengaruh model latihan kesimbangan Badgan terhadap hasil pemanjatan pada olahraga panjat dinding untuk pemanjat pemula, (2). Terdapat pengaruh model latihan keseimbangan konvensional terhadap hasil pemanjatan pada olahraga panjat dinding untuk pemanjat pemula, (3). Terdapat perbedaan pengaruh antara model latihan keseimbangan Badgan dan model latihan keseimbangan konvensional terhadap hasil pemanjatan pada olahraga panjat dinding untuk pemanjat pemula. (4).Pengaruh model latihan keseimbangan Badgan lebih baik dari pada model latihan keseimbangan konvensional.

\section{REFERENSI}

Djoko Nugroho. 2013. Jurnal Media Ilmu Keolahragaan Indonesia. Semarang

Maksum, A. 2009. Metodologi Penelitian. Surabaya: Unesa University Press.

Soegiyanto KS. 2004. Sistem Pembinaan Olahraga Prestasi (Makalah dalam Seminar Nasional Pembinaan Olahraga Dilingkungan TNI dan POLRI Kerjasama FIK UNNES dengan DIRJEN Olahraga. Semarang: Depdiknas.

Sudjana. 2002. Metode Statistika Edisi ke-6. Bandung: Tarsito.

Widiastuti. 2011. Tes dan Pengukuran Olahraga Jakarta: PT Bumi Timur Jaya.

Yunyun Yudiana. 2009. Materi Pokok Dasar-dasar Kepelatihan. Jakarta: Universitas Terbuka. 